\title{
Terrorist Attack: The Psychological Response of the Survivors
}

\author{
Dr. Karavadi Vidusha ${ }^{1}$
}

\begin{abstract}
This study explored the socio-economic and psychological impact of terrorist attacks on the lives of survivors. Although several years may have passed since the incident, it will take time $\mathrm{t}$ for respondents to recover from the impact. The survivors still have wounds to remind them of the horrific ordeal. They are plagued with psychological problems, and these problems are often more difficult than the problems and pain caused by physical injuries. Most people often experience stress-related psychological symptoms as well as other related symptoms such as sadness, depression, anxiety, inability to focus on daily activities, nightmares, and flashbacks. In addition, terrorist attacks cause serious long-term socio-economic impacts on survivors, including unemployment, uncertainty in children's education, and deteriorating health. In addition to the deteriorating socio-economic conditions, the most pressing problems faced by this group of survivors are insufficient government support and lack of follow-up actions in rehabilitation. These problems must be addressed urgently and fully. Months after the attack, the use of primary and secondary health services by young survivors emphasized the importance of allocating resources to meet the growing demand for services over a longer period of time. The results further emphasize the need to address the physical symptoms of disaster survivors receiving mental health services. Thus, it is easier to provide costly evidencebased therapies and treatments to affected people in countries with less fragile health systems than in resource-poor settings. It is important to better understand alternative interventions and mechanisms and social options for providing care in the most vulnerable countries, and to develop strategies to use them effectively.
\end{abstract}

Keywords: Terrorism, Victims, Trauma, Psychiatric help, Mental Health, Physical Symptoms, public health system

\footnotetext{
${ }^{1}$ Dr. Karavadi S. Vidusha, M.D., is Associate Professor, Department of Community Medicine, Rajarajeswari Medical College and Hospital, Kambipura, Mysore Road, Bangalore.
} 


\section{Terrorist Attack: The psychological Response of the Survivors}

In the path of a normal lifespan, most people face several unpleasant events. Such events can be stressful and, for some, unbearable (Bonanno,2010). There are more and more lifethreatening and health-threatening situations in society, and their consequences and their impact on individuals or society need to be carefully studied (Kharash ,1996, Zinchenko 2012). A terrorist attack is the most terrifying extreme situation. While any situation can provoke a personal psychological reaction, intentional violence by one person or group of people can have the strongest impact on victims damaging their health and causing physical harm. (Soldatova, 2008; Zinchenko 2008)

The profound effects of disasters can have multiple psychological effects (Raphael and Maguire, 2009). The biggest question is how bad these consequences will be and to whom. Can people survive the disaster without lasting psychological harm, and if so, how many can? (Bonanno, 2010)

Unlike storms or floods, chemical disasters occur almost without warning, followed by fears of illness and premature death (Bowler et al., 1997) and fears of possible genetic or congenital birth defects in the offspring. In the context of terrorism, especially when the attacker is unknown, the potential expression of anger cannot be used from any suitable source, creating a sense of futility, low morale and despair. (National Academy of Sciences Press, 1999). Acts of terrorism occur in almost all countries. The casualties caused by the attack are only a means to an end. (Duck, 2020). Terrorism is a scheme used by individuals and groups to modify countries, policies or policies. Attacks expose people to violence, threats, and traumatic events. (Duckers, 2020) (Michael) Terrorist attacks are a major public health challenge due to their unforeseen destructive effects. Many deaths occurred in 4,444 cases, causing serious physical and mental health problems for the survivors. (Stene, 2015) The survivors not only suffer physical injury but also will undoubtedly go through extreme psychological trauma (Bowler et al., 1997)

In communities geographically remote from the attack, terrorist attacks can have widespread effects on mental health (Duckers, 2020) Acute traumatic stress is more common and usually subsides within a few weeks, but some survivors will appear persistent mental health problems (Bonanno, 2010; Neria, 2011). Post-traumatic stress disorder (PTSD) and depression are the most common mental disorders after a terrorist attack. (Neria,2011; Whalley,2007) In this 
article, we will first describe some of the potential consequences of direct exposure to terrorist attacks, paying particular attention to the mental and physical health of survivors and their daily functions (Glad,2021).

\section{Terrorism}

The Global Terrorism Database has record of incidents of terrorism from 1970 onward. (START). For the database, to be classified as a terrorist attack, the incident must meet three criteria. First, the attack must be aimed at achieving political, economic, religious or social objectives. Second, there must be proof of intent to, or convey some other message to an audience larger than the direct victim. Third, the action must be outside the scope of lawful war activities (Regens,2015).

The 2018 Global Terrorism Index report stated that total number of deaths from terrorism was 18,814 deaths in 2017.Countries like Afghanistan 25\%; Iraq 23\%; Nigeria 8\%; Somalia 8\%; Syria 6\%; Pakistan 5\%; Egypt 3\%; Democratic Republic of Congo 3\%; Central African Republic 2\%; India $2 \%$ accounted for $84 \%$ of deaths from terrorism (Global Terrorism Index 2018).

\section{Psychological effects of terrorism-Long-Term Effects of Terrorism}

Post-traumatic stress disorder (PTSD) is the most studied mental disorder and can occur after a traumatic event, such as a terrorist attack.(Glad,2021) Many studies on civilian terrorist attacks report Very high incidence of post-traumatic stress disorder, such as post-attack stress disorder (PTSD). (National Academy Press,1999) Typical symptoms of PTSD are reexperiencing the incident as if it is happening again, including disturbing thoughts and images of the event, nightmares, and flashbacks; try to avoid places or thoughts that remind you of the attack; and experiencing sleep disturbance, inattention, excessive startle response, and irritability Many people experience negative emotions in their thoughts and feelings after the event, including thoughts about themselves (e.g., "I'm weak") or the world (e.g., "Nowhere is safe") (American Psychiatric Association ,2013) In a recent systematic review on PTSD among terrorist attack survivors, Garcia-Vera et al. (2016) reported that $33 \%$ to $39 \%$ of those directly exposed to a terrorist attack developed PTSD within the first year.(García-Vera,2016) In addition, they found that $15 \%$ to $26 \%$ still had PTSD after 6 to 7 years of the attack. In a study by Abenhaim, Dab, and Salmi (1992) in France among 254 survivors of terrorist attacks over 
a period of five years found that prevalence of PTSD among severely injured was 30.7\%, and among uninjured victims it was 10.5 percent (Abenhaim,1992)

Several studies have pointed out that depression is a common co-morbidity of PTSD. Along with the PTSD, many victims of the terrorist attack also suffered the death of family members, close friends or colleagues, which may lead to bereavement, which in itself increases the risk of depression, self-medication, and substance abuse. (National Academy Press, 1999)

Terrorist attacks are always unexpected and sudden and can cause great trauma. The psychological outcome of these attacks is the most disturbing type of disaster and (Norris, 2001; Khan, Sahandi, Hussein, Iqbal, and Rizwan, 2012), which may include mixture of reactions (Khan et al. People, 2012). These reactions can vary from person to person, depending on many factors, such as: the severity and extent of the damage, the proximity to the explosion, the cruelty of the incident, and the coping mechanism (Greenberg, Simon, Pyszczynski, Solomon \& Chatel,1992).

It is complicated to find individuals who are at risk of long-term psychological effects in time, because PTSD symptoms themselves are less effective in predicting mental outcomes days after the traumatic event. (Shalev, 1992). Neuropsychological test is recommended to assess the impact on cognition, memory, and personality, as well as the possible organic sequelae of chemical agents used in terrorist attacks. (National Academy Press, 1999) This will help early and immediate or long-term psychiatric treatment.

\section{Short-Term Effects of Terrorism (Acute Needs)}

In the acute phase after a terrorist attack, panic can cause victims and first responders (Hazmat teams, police, fire, and medical) to weaken the supporting infrastructure. The severity of these events highlights the urgent need for stable and specific mental health support to anticipate psychological responses to chemical or biological terrorist attacks (National Academy Press, 1999)

In addition to the other common forms of psychopathology that survivors of a terrorist attack may experience, there is anxiety and depression. (Thabet, 2016) In the systematic review of Salguero et al. (2011) found that the risk of major depression after a terrorist attack ranges between $20-30 \%$ in the first few months after an attack among those directly exposed (Salguero,2011) 
The traumatic loss of a loved one in a terrorist attack can lead to a severe and long-lasting psychological response and Grief is a normal response .The characteristic feature of grief is "constant, intense desire, and sadness, This is accompanied by concrete thoughts of the deceased and a sense of disbelief or an inability to accept the painful truth of the person is dead."(Shear, 2015)

Previous studies have found that post-traumatic stress disorder and other behavioral and health disorders are common results after terrorist attacks (Galea, Nandi, and Vlahov, 2005), and twothirds of affected victims have some degree of psychological disorder ( Beaton and Murphy, 2005). 2002). In addition to PTSD, many people also suffer from anxiety, depression, and substance use disorders. (Abenhaim, Dab, \&Salmi,1992; North, et al.,1999).

\section{Socio-economic effects of terrorism}

The economic impact of terrorist activities can be diverse. There are many direct losses, such as loss of life and property. Terrorist attacks can damage infrastructure and businesses (Gaibulloev and Sandler, 2009). It is estimated that transnational terrorism will reduce the per capita growth rate by $0.038 \%$ to $0.048 \%$ (Gaibulloev and Sandler, 2009). Sandler and Enders (2008) also reported that small developing countries have experienced major macroeconomic impact due to terrorism (Sandler,2008)

In fact, the impact of terrorism on society may even be more serious and far-reaching than the economic impact. Due to such terrorist activities, the social welfare of all countries has been affected. (Waxman, 2011). In addition to dealing with the loss of family members, survivors have to deal with many other issues. Such attacks can destroy people's entire social support system, which in itself can cause great trauma, especially for those who have lost the only family member who makes money. (Hussain,2016) Terrorist attacks can destroy all aspects of survivors' health, including their physical, psychological and social well-being. Although these aspects of health are seriously intertwined with post-traumatic ones, the symptoms that originate or are related to the body (or soma) must be resolved. (Asmundson, 2009) The physical symptoms of survivors after an attack can be caused directly by exposure to a wide range of physical hazards, such as forceful penetration or toxic, infectious or radioactive or irritating substances (Lippmann ,2015; Lucchini ,2017; Neria 2013) In the first weeks after the trauma, common physical symptoms such as palpitations, headaches, pain, fatigue, or insomnia. (Kizilhan, 2018). These symptoms are understood as temporary and normal reactions 
and do not require further follow-up . However, large epidemiological studies have indicated that frequent and persistent headaches, pain, and other physical symptoms can cause serious dysfunction. (Mokdad, 2016) high-level physical symptoms and related dysfunctions in the early post-traumatic stage can compromise survivors' ability to complete daily tasks, such as preparing and eating healthy meals, ensuring good sleep hygiene and avoiding excessive use of pain relievers and alcohol. If the physical symptoms are more severe and long-lasting than previously thought, they can make it difficult to regain healt ( Bilevicius ,2018)

The impact of terrorism on mental health is also affected by the difference in the mental health of the national population. Several epidemiological studies have observed variation in the prevalence of common trauma-related mental health disorders such as anxiety, mood disorders, and substance use disorders, especially post-traumatic stress disorder and depression (Kessler, 2008;2013;2017, WHO, 2014 Preventing suicide: A global imperative). Various authors have shown an association between prevalence of trauma-related disorders and cultural \& socioeconomic characteristics, (Burri,2014; Dückers,2016;2016;2019). It has been reported that the socioeconomic disturbances are associated with general anxiety disorder and adult ADHD (Fayyad et.al,2017; Ruscio et.al,2017). Such studies suggest that the difference is not random but linked to the same factors that influence the provision of professional evidencebased mental healthcare (Dückers ,2020)

\section{The Effects of Terrorism on Children}

Young survivors of terrorist attacks are particularly vulnerable. (Wu, 2006; Chemtob, 2009; Schiff, 2007) Among children and adolescents who have experienced disasters, the prevalence of post-traumatic stress disorder (PTSD) ranges from 1\% to 60\%. (Wang, 2013).It has been reported from the previous studies that young people exposed to terrorist attacks had increased rates of mental health disorders for isolated attacks occurring in countries that were not at war(e.g., Oklahoma City bombing, September 11th 2001) (Comer,2007)

Many studies have clearly assessed children's responses to terrorist incidents. Nearly a year after the explosion of the Alfred P. Murrah Federal Building in Oklahoma City, approximately $5 \%$ of elementary school students reported clinically significant symptoms of PTSD (Gurwitch et al., 2002). A year later, among high school students who lived 100 miles from the city, nearly $20 \%$ reported bomb-related symptoms affecting their home or school functions (Pfefferbaum et al., 2000). In addition to the "dose" or degree of attack, the degree of life interruption, the 
family support available during the event and after the trauma, and the degree of social disorder are key predictors of health symptoms. In view of the fact that past trauma exposure is a potent risk factor for psychopathology in response to a subsequent traumatic exposure (Yehuda,2005)

Adolescents are more likely to use drugs to resolve their symptoms. Studies conducted after the terrorist attack in Israel and after September 11, 2001, showed that adolescent use of illegal substances, alcohol, and nicotine has increased (Wu, 2006; Chemtob, 2009; Schiff, 2007). There is no doubt that post-traumatic stress is more likely to harm their academic success and psychosocial development, and has potential long-term effects (Eisenberg, 2011). Therefore, they may need continuous and long-term health monitoring in primary and secondary care. (Stene,2015).

Understanding the difference between the effects of terrorism on the mental health of adults and children after trauma is absolutely necessary for the development of appropriate intervention strategies, because terrorism affects youth and adults (Yehuda ,2005)

\section{Terrorism Risk and Interventions: a Developmental Framework}

In treating children, an main issue that arises is whether, and to what extent, post-traumatic interventions for adults can be used for children. Many psychotherapy methods use some form of cognitive behavioral therapy (CBT), and children have cognitive abilities. However, it is clear that some form of cognitive ability is essential for the improvement of post-traumatic psychopathology (Kar,2011). For example, infants are protected from total psychological "exposure" to terrorism due to their cognitive immaturity; on the other hand, adolescents can understand the sheer horror of such incidents. However, babies will be very vulnerable to caregiver decline because they are completely reliant on adult care. Once children become attached to their caregivers, they are very sensitive to separation and loss, especially when they are anxious. Children gauge threats based on the response of the caregiver. Since worried parents are terrifying to their children, parents can alleviate or mediate the spread of terror as the carrier of the spread of fear to children. Parents, teachers, and other calm, functional adults can encourage children (Pine, 2005). Also, it is not clear whether the same medications should be used in children as in adults with post-traumatic syndrome. One of the main gaps in our knowledge is that few studies have examined the effectiveness of any intervention for children after large-scale disasters or terrorism. This should be a high priority (Yehuda,2005) 


\section{Treatment}

Due to the continuing need for medical and physical rehabilitation, psychological treatment for trauma victims is always difficult. In the case of terrorist attacks against civilians, due to the fact that the attacks often occur in the everyday environment, it becomes more complicated to return. Therefore, community treatment methods should include education about reminders and the effects of environmental changes to minimize unnecessary and avoidable secondary trauma (National Academy Press,1999). Vulnerable groups, such as families with children, frail elderly and disabled people, may need additional services. They must receive basic medical and social services, including treatment therapeutic support of their fears, and ensure that they respond normally to abnormal events (Bisson and Deahl, 1994).

\section{Interventions Following Terrorist Acts}

Research so far has focused on two types of interventions, i.e. Critical Incident Stress Debriefing (CISD; Mitchell, 1983) and a brief CBT which were carried out shortly after the traumatic event, with the goal of preventing chronic stress reactions. The most important thing is debriefing is administered to all exposed people, while CBT is only done to those who have symptoms.

Earlier studies reported that use of drugs such as propranolol (Pitman et al., 2002) block the role of stress hormones in the consolidation of traumatic memories or cortisol (Schelling et al., 2004). Current neuroscientific research hypothesizes that "retelling" within a few hours of a traumatic experience, especially if a strong emotional response is fostered, may lead to further consolidation of traumatic memories. Promising interventions include a brief CBT, which includes four to five meetings that begin 2-5 weeks after the traumatic event. However, no data have yet been published on the efficacy of this therapy for terrorist survivors. (Yehuda ,2005).

It is important to understand the impact of the media on the population and respond to the challenge of using the media to promote positive messages that promote resilience. This step requires systematic research. It is also important to explore the possibility of the media as a means of helping citizens regulate post-traumatic anxiety (Charuvastra,2008). Over time, information about abnormal response and where to get help can also be passed on so viewers can accurately assess their (or loved ones) mental state. In this way, vulnerable people can identify themselves as soon as possible and turn to appropriate professional assistance. (Yehuda, 2005) 
Communities and countries differ in their ability to provide the required disaster/terrorism response and high-quality healthcare. The countries least vulnerable to lack of service delivery capacity are those with higher incomes, which score higher in terms of good governance, lower levels of corruption, higher levels of public and private health expenditures, and easier access to general practitioners and hospitals. It can be said that it is easier to provide expensive evidence-based therapies and treatments to affected populations with a well-developed health system than in a resource-poor environment. This is confirmed by a recent analysis by Evans Lacko and colleagues, which covers 25 countries. Among the cases diagnosed with anxiety, mood, and substance abuse disorders, the rate was $13.7 \%$ in low- and middle-income countries, $22.0 \%$ in high- and middle-income countries, and 36.8\% in low- and middle-income countries. (Evan et.aal, 2018). Another study identified barriers to accessing mental health treatment in a sample of 24 countries. (Andrade, 2014)

In practice, depending on the location of the attack, the best response requires well-organized interdisciplinary work, served by professionals from various organizations and institutions, well-trained volunteers, and community workers.(Patel,2010) In more fragile and resourcepoor societies, the ability to meet urgent needs and professional services is scarce compared to less fragile regions. International humanitarian assistance programs, peacekeeping missions and non-governmental organizations can play a key role in poor areas by supplementing the assistance capabilities and resources required to provide recommended services at prime time and stage. (Dückers,2020)

Providing care in vulnerable countries requires different interventions and mechanisms and societal choices, as well as strategies to effectively use them as successful and satisfactory substitute. Families, religious and spiritual organizations can play a natural supporting role here, especially in terms of basic services and community and family safety and support. (Rahman 2016)

In the past 20 years, significant progress has also been made in understanding key nonspecialist support and specialized clinical mental health care in low- and middle-income countries. Examples include group psychotherapeutic interventions and individualized interventions led by non-professional health workers in primary care institutions (Bolton,2003). It is only a matter of time before other interventions are ready to scale up, and this process can even be helped by the increased global availability of smart phones and data. 
Still, the potential to strengthen early detection and treatment of mental health problems around the world looks promising, perhaps better than ever. At the same time, on the road to reducing vulnerability and implementing evidence-based medicine, there are always obstacles and challenges that need to be resolved. Systematic investigations of what works and what works in different populations and settings remain invaluable. (Patel,2011)

\section{Conclusion}

Yet, there are troubling gaps in our knowledge about the long-term effects of terrorism on brain, behavior, and physical health, the risk factors for predicting who will be most affected by terrorism and interventions that might promote resilience at an individual and population level. This information is essential in reducing the damage done by terrorists to the psyche of our nation.However, there is a worrying gap in our knowledge of the long-term effects of terrorism on brain, behavior, and physical health, predicting who will be most affected by terrorism and interventions that can promote the resilience of individuals and populations. grade. This information is essential to reduce the damage caused by terrorists to the spirit of our country.

Providing care in vulnerable countries requires different interventions and societal mechanisms and options, as well as strategies to use them effectively as successful and satisfying alternatives.

\section{Acknowledgement}

The Author would like to extend my gratitude to Group Captain Rajamanickam Srinivasan VSM (Retd), PhD who provided insight and expertise that greatly assisted the research.

\section{References}

1. Abenhaim L, Dab W, Salmi LR. 1992. Study of civilian victims of terrorist attacks (France, 1982-1987). Journal of Clinical Epidemiology 45(2):103-109.

2. American Psychiatric Association. (2013). Diagnostic and Statistical Manual of Mental Disorders: DSM-5 (Fifth edition. ed.). Arlington, VA: American Psychiatric Association. 
3. Andrade, L. H., Alonso, J., Mneimneh, Z., Wells, J. E., Al-Hamzawi, A., Borges, G., Bromet, E., Bruffaerts, R., de Girolamo, G., de Graaf, R., Florescu, S., Gureje, O., Hinkov, H. R., Hu, C., Huang, Y., Hwang, I., Jin, R., Karam, E. G., Kovess-Masfety, V., Levinson, D., ... Kessler, R. C. (2014). Barriers to mental health treatment: results from the WHO World Mental Health surveys. Psychological medicine, 44(6), 1303-1317. https://doi.org/10.1017/S0033291713001943

4. Asmundson, G. J. G., \& Katz, J. (2009). "Understanding the Co-occurrence of Anxiety Disorders and Chronic Pain: State-of-the-Art," Depression and Anxiety, 26(10), pp. 888-901.

5. Beaton, R. \& Murphy, S. (2002). Psychosocial responses to biological and chemical terrorist threats andevents: implications for theworkplace. Journal of the American Association of Occupational HealthNurses, 50,182-189.

6. Bilevicius, E., Sommer, J. L., Asmundson, G. J. G., \& El-Gabalawy, R. (2018). "Posttraumatic Stress Disorder and Chronic Pain are Associated with Opioid Use Disorder: Results from a 2012-2013 American Nationally Representative Survey," Drug and Alcohol Dependence, 188, pp. 119-125. DOI:10.1016/j.drugalcdep.2018.04.005

7. Bisson JI, Deahl MP. 1994. Psychological debriefing and prevention of posttraumatic stress. British Journal of Psychiatry 165:717-720.

8. Bolton, P., Bass, J., Neugebauer, R., Verdeli, H., Clougherty, K. F., Wickramaratne, P., Speelman, L., Ndogoni, L., \& Weissman, M. (2003). Group interpersonal psychotherapy for depression in rural Uganda: a randomized controlled trial. JAMA, 289(23), 3117-3124. https://doi.org/10.1001/jama.289.23.3117

9. Bonanno, G. A., Brewin, C. R., Kaniasty, K., \& Greca, A. M. (2010).

Weighing the Costs of Disaster: Consequences, Risks, and Resilience in Individuals, Families, and Communities. Psychological science in the public interest : a journal of the American Psychological Society, 11(1), 1-49.

https://doi.org/10.1177/1529100610387086

10. Bowler RM, Huel D, Mergler G, Cone JE. 1994. Psychological, psychosocial, and psychophysiological sequelae in a community affected by a railroad chemical disaster. Journal of Traumatic Stress 7:601-624.

11. Burri, A., \& Maercker, A. (2014). Differences in prevalence rates of PTSD in various European countries explained by war exposure, other trauma and cultural value orientation. BMC research notes, 7, 407. https://doi.org/10.1186/1756-0500-7$\underline{407}$

12. Charuvastra, A., \& Cloitre, M. (2008). Social bonds and posttraumatic stress disorder. Annual review of psychology, 59, 301-328. https://doi.org/10.1146/annurev.psych.58.110405.085650

13. Chemtob, C. M., Nomura, Y., Josephson, L., Adams, R. E., \& Sederer, L. (2009). Substance use and functional impairment among adolescents directly exposed 
to the 2001 World Trade Center attacks. Disasters, 33(3), 337-352.

https://doi.org/10.1111/j.1467-7717.2008.01077.x

14. Comer, J., \& Kendall, P. (2007). Terrorism: The psychological impact on youth. Clinical Psychology: Science And Practice, 14(3), 179-212. doi: 10.1111/j.1468-2850.2007.00078.x

15. Dückers, M. L., \& Brewin, C. R. (2016). A Paradox in Individual Versus National Mental Health Vulnerability: Are Higher Resource Levels Associated With Higher Disorder Prevalence?. Journal of traumatic stress, 29(6), 572-576. https://doi.org/10.1002/jts.22144

16. Dückers, M. L., Alisic, E., \& Brewin, C. R. (2016). A vulnerability paradox in the cross-national prevalence of post-traumatic stress disorder. The British journal of psychiatry : the journal of mental science, 209(4), 300-305. https://doi.org/10.1192/bjp.bp.115.176628

17. Dückers, M., Reifels, L., De Beurs, D. P., \& Brewin, C. R. (2019). The vulnerability paradox in global mental health and its applicability to suicide. The British journal of psychiatry: the journal of mental science, 1-6. Advance online publication. https://doi.org/10.1192/bjp.2019.41

18. Dückers, M., Ursano, R., \& Vermetten, E. (2020). A Global Perspective on the Mental Health Response to Terrorism. In E. Vermetten, I. Frankova, L. Carmi, O. Chaban, \& J. Zohar (Eds.), Risk Management of Terrorism Induced Stress: Guidelines for the Golden Hours (Who, What and When) (pp. 10-18). (NATO Science for Peace and Security Series). IOS Press. https://doi.org/10.3233/NHSDP200004

19. Eisenberg, N., \& Silver, R. C. (2011). Growing up in the shadow of terrorism: youth in America after 9/11. The American psychologist, 66(6), 468-481.

https://doi.org/10.1037/a0024619

20. Evans-Lacko, S., Aguilar-Gaxiola, S., Al-Hamzawi, A., Alonso, J., Benjet, C., Bruffaerts, R., Chiu, W. T., Florescu, S., de Girolamo, G., Gureje, O., Haro, J. M., He, Y., Hu, C., Karam, E. G., Kawakami, N., Lee, S., Lund, C., Kovess-Masfety, V., Levinson, D., Navarro-Mateu, F., ... Thornicroft, G. (2018). Socio-economic variations in the mental health treatment gap for people with anxiety, mood, and substance use disorders: results from the WHO World Mental Health (WMH) surveys. Psychological medicine, 48(9), 1560-1571. https://doi.org/10.1017/S0033291717003336

21. Fayyad, J., Sampson, N. A., Hwang, I., Adamowski, T., Aguilar-Gaxiola, S., AlHamzawi, A., Andrade, L. H., Borges, G., de Girolamo, G., Florescu, S., Gureje, O., Haro, J. M., Hu, C., Karam, E. G., Lee, S., Navarro-Mateu, F., O'Neill, S., Pennell, B. E., Piazza, M., Posada-Villa, J., ... WHO World Mental Health Survey Collaborators (2017). The descriptive epidemiology of DSM-IV Adult ADHD in the World Health Organization World Mental Health Surveys. Attention deficit and hyperactivity disorders, 9(1), 47-65. https://doi.org/10.1007/s12402-016-0208-3

22. Gaibulloev,K.\&Sandler,T. (2009).The impact of terrorism and con $£$ icts on growth in Asia. Economics and Politics, 21, 359-383. 
23. Galea, S.,Nandi,A.,\&Vlahov,D. (2005).The epidemiology of Post-Traumatic StressDisorder after disasters. Epidemiologic Review, 27,78-91.

24. Glad, K., Stensland, S., \& Dyb, G. (2021). The Terrorist Attack on Utøya Island: Long-Term Impact on Survivors' Health and Implications for Policy. $<\mathrm{i}>$ Perspectives on Terrorism, $</ \mathrm{i}><\mathrm{i}>15</ \mathrm{i}>(3), 60-74$. Retrieved August 17, 2021, from https://www.jstor.org/stable/27030882

25. Greenberg, J., Simon, L., Pyszczynski, T., Solomon, S., \& Chatel, D. (1992).Terror management and tolerance: does mortality salience always intensify negative reactions to others who threaten one's world view? Journal of Personality and Social Psychology, 63, 212-220.

26. Gurwitch, R.H., Sitterle, K. S.,Young, B.H., et al (2002) The aftermath of terrorism. In Helping Children Cope with Disasters: Integrating Research and Practice (eds A.M. La Greca \& W.K. Silverman), pp. 327-357. American Psychological Association.

27. Hussain, D., \& Sarma, R. (2016). Socio-economic and psychological effects of terrorist bomb blasts on the lives of survivors. Intervention, 14(3), 189-199. doi: $10.1097 / \mathrm{wtf} .0000000000000121$

28. Institute for Economics \& Peace, Global Terrorism Index 2018: measuring the impact of terrorism, Sidney. (2021). Retrieved 17 August 2021, from https://www.economicsandpeace.org/wp-content/uploads/2020/08/Global-Terrorism-Index2018.pdf

29. Kar N. (2011). Cognitive behavioral therapy for the treatment of post-traumatic stress disorder: a review. Neuropsychiatric disease and treatment, 7, 167-181. https://doi.org/10.2147/NDT.S10389

30. Kessler, R. C., \& Bromet, E. J. (2013). The epidemiology of depression across cultures. Annual review of public health, 34, 119-138. https://doi.org/10.1146/annurevpublhealth-031912-114409

31. Kessler, R. C., Aguilar-Gaxiola, S., Alonso, J., Benjet, C., Bromet, E. J., Cardoso, G., Degenhardt, L., de Girolamo, G., Dinolova, R. V., Ferry, F., Florescu, S., Gureje, O., Haro, J. M., Huang, Y., Karam, E. G., Kawakami, N., Lee, S., Lepine, J. P., Levinson, D., NavarroMateu, F., ... Koenen, K. C. (2017). Trauma and PTSD in the WHO World Mental Health Surveys. European journal of psychotraumatology, 8(sup5), 1353383. https://doi.org/10.1080/20008198.2017.1353383

32. Kessler, R. C., Aguilar-Gaxiola, S., Alonso, J., Chatterji, S., Lee, S., Ormel, J., Ustün, T. B., \& Wang, P. S. (2009). The global burden of mental disorders: an update from the WHO World Mental Health (WMH) surveys. Epidemiologia e psichiatria sociale, 18(1), 23 33. https://doi.org/10.1017/s1121189x00001421

33. Khan,A.M., Sahandi, I.,Hussain, J., Iqbal, S., \&Rizwan,T. (2012). Impact of Terrorism on Mental Health. AnnalsofPakistanInstituteofMedicalSciences, 8, 46-49. 
34. Kharash AU.(1996) Humanitarian assessment in extreme situations: Ideology, Methodology, Procedure. In: Introduction to practical social psychology, Moscow: Smisl; , p. 86129.

35. Kizilhan, J. I., \& Noll-Hussong, M. (2018). "Post-Traumatic Stress Disorder Among Former Islamic State Child Soldiers in Northern Iraq," British Journal of Psychiatry, 213(1), 425-429. doi:10.1192/bjp.2018.88

36. Lippmann, M., Cohen, M. D., \& Chen, L. C. (2015). "Health Effects of World Trade Center (WTC) Dust: An Unprecedented Disaster's Inadequate Risk Management," Critical Reviews in Toxicology, 45(6), pp. 492-530. DOI:10.3109/10408444.2015.10446 01

37. Lucchini, R. G., Hashim, D., Acquilla, S., Basanets, A., Bertazzi, P. A., Bushmanov, A., Todd, A. C. (2017). "A Comparative Assessment of Major International Disasters: The Need for Exposure Assessment, Systematic Emergency Preparedness, and Lifetime Health Care," BMC Public Health, 17(1), p. 46. DOI:10.1186/s12889-016-3939-3

38. Mitchell J. T. (1983). When disaster strikes...the critical incident stress debriefing process. JEMS : a journal of emergency medical services, 8(1), 36-39.

39. Mokdad, A. H., Forouzanfar, M. H., Daoud, F., Mokdad, A. A., El Bcheraoui, C., Moradi-Lakeh, M.,Murray, C. J. (2016). "Global Burden of Diseases, Injuries, and Risk Factors for Young People's Health During 1990-2013: A Systematic Analysis for the Global Burden of Disease Study 2013," Lancet, 387(10036), pp. 2383-2401. DOI:10.1016/s01406736(16)00648-6

40. National Academy Press. (1999). Chemical and Biological Terrorism: Research and Development to Improve Civilian Medical Response. Washington, D.C.

41. Neria, Y., DiGrande, L., \& Adams, B. G. (2011). Posttraumatic stress disorder following the September 11, 2001, terrorist attacks: a review of the literature among highly exposed populations. The American psychologist, 66(6), 429-446.

https://doi.org/10.1037/a0024791

42. Neria, Y., Wickramaratne, P., Olfson, M., Gameroff, M. J., Pilowsky, D. J., Lantigua, R., Weissman, M. M. (2013). "Mental and Physical Health Consequences of the September 11, 2001 (9/11) Attacks in Primary Care: A Longitudinal Study," Journal of Traumatic Stress, 26(1), pp. 45-55. DOI:10.1002/jts.21767

43. Norris, F. H. (2001). Fifty thousand disaster victims speak: An empirical review of the empirical literature, 1981^2001. Retrieved from: http://obssr.od.nih. gov/pdf/disasterimpact.pdf

44. North,C. S.,Nixon, S. J., Shariat, S.,Mallonee, S., McMillen, J. C., Spitznagel, E. L. , $\&$ Smith, E. M. (1999). Psychiatric disorders among survivors of the Oklahoma City bombing.JournaloftheAmericanMedical Association, 282,755-762.

45. Patel, V., Weiss, H. A., Chowdhary, N., Naik, S., Pednekar, S., Chatterjee, S., De Silva, M. J., Bhat, B., Araya, R., King, M., Simon, G., Verdeli, H., \& Kirkwood, B. R. (2010). Effectiveness of an intervention led by lay health counsellors for depressive and 
anxiety disorders in primary care in Goa, India (MANAS): a cluster randomised controlled trial. Lancet (London, England), 376(9758), 2086-2095. https://doi.org/10.1016/S0140$\underline{6736(10) 61508-5}$

46. Patel, V., Weiss, H. A., Chowdhary, N., Naik, S., Pednekar, S., Chatterjee, S., Bhat, B., Araya, R., King, M., Simon, G., Verdeli, H., \& Kirkwood, B. R. (2011). Lay health worker led intervention for depressive and anxiety disorders in India: impact on clinical and disability outcomes over 12 months. The British journal of psychiatry : the journal of mental science, 199(6), 459-466. https://doi.org/10.1192/bjp.bp.111.092155

47. Paz García-Vera, M., Sanz, J., \& Gutiérrez, S. (2016). A Systematic Review of the Literature on Posttraumatic Stress Disorder in Victims of Terrorist Attacks. Psychological reports, 119(1), 328-359. https://doi.org/10.1177/0033294116658243

48. Pfefferbaum, B., Seale,T.W.,McDonald,N. B., et al (2000) Posttraumatic stress two years after the Oklahoma City bombing in youths geographically distant fromthe explosion. Psychiatry, 63, 358-370.

49. Pine, D. S., Costello, J., \& Masten, A. (2005). Trauma, proximity, and developmental psychopathology: the effects of war and terrorism on children. Neuropsychopharmacology: official publication of the American College of Neuropsychopharmacology, 30(10), 17811792. https://doi.org/10.1038/sj.npp.1300814

50. Pitman, R. K., Sanders, K. M., Zusman, R. M., Healy, A. R., Cheema, F., Lasko, N. B., Cahill, L., \& Orr, S. P. (2002). Pilot study of secondary prevention of posttraumatic stress disorder with propranolol. Biological psychiatry, 51(2), 189-192.

https://doi.org/10.1016/s0006-3223(01)01279-3

51. Preventing suicide: A global imperative. (2014). Retrieved 17 August 2021, from https://www.who.int/publications-detail-redirect/9789241564779

52. Rahman, A., Hamdani, S. U., Awan, N. R., Bryant, R. A., Dawson, K. S., Khan, M. F., Azeemi, M. M., Akhtar, P., Nazir, H., Chiumento, A., Sijbrandij, M., Wang, D., Farooq, S., \& van Ommeren, M. (2016). Effect of a Multicomponent Behavioral Intervention in Adults Impaired by Psychological Distress in a Conflict-Affected Area of Pakistan: A Randomized Clinical Trial. JAMA, 316(24), 2609-2617.

https://doi.org/10.1001/jama.2016.17165

53. Raphael, B., \& Maguire, P. (2009). Disaster mental health research:Past, present, and future. In Y. Neria, S. Galea, \& F.H. Norris (Eds.), Mental health and disasters (pp. 7-28). New York: Cambridge University Press.

54. Regens, J. L., Schultheiss, A., \& Mould, N. (2015). Regional Variation in Causes of Injuries among Terrorism Victims for Mass Casualty Events. Frontiers in public health, 3, 198. https://doi.org/10.3389/fpubh.2015.00198

55. Ruscio, A. M., Hallion, L. S., Lim, C., Aguilar-Gaxiola, S., Al-Hamzawi, A., Alonso, J., Andrade, L. H., Borges, G., Bromet, E. J., Bunting, B., Caldas de Almeida, J. M., Demyttenaere, K., Florescu, S., de Girolamo, G., Gureje, O., Haro, J. M., He, Y., Hinkov, H., $\mathrm{Hu}, \mathrm{C}$., de Jonge, P., ... Scott, K. M. (2017). Cross-sectional Comparison of the 
Epidemiology of DSM-5 Generalized Anxiety Disorder Across the Globe. JAMA psychiatry, 74(5), 465-475. https://doi.org/10.1001/jamapsychiatry.2017.0056

56. Salguero, J.M., Fernández-Berrocal, P., Iruarrizaga, I., et al. (2011). "Major Depressive Disorder Following Terrorist Attacks: A Systematic Review of Prevalence, Course and Correlates," BMC Psychiatry, 11, p. 96.

57. Sandler, T. \& Enders,W. (2008). Economic consequences of terrorism in developed and developing countries: An overview. In: P. Keefer \& N. Loayza (Eds.) Terrorism, Economic Development and Political Openness ( 17-47). Cambridge, UK: Cambridge University Press.

58. Schelling, G., Kilger, E., Roozendaal, B., de Quervain, D. J., Briegel, J., Dagge, A., Rothenhäusler, H. B., Krauseneck, T., Nollert, G., \& Kapfhammer, H. P. (2004). Stress doses of hydrocortisone, traumatic memories, and symptoms of posttraumatic stress disorder in patients after cardiac surgery: a randomized study. Biological psychiatry, 55(6), 627-633. https://doi.org/10.1016/j.biopsych.2003.09.014

59. Schiff, M., Zweig, H. H., Benbenishty, R., \& Hasin, D. S. (2007). Exposure to terrorism and Israeli youths' cigarette, alcohol, and cannabis use. American journal of public health, 97(10), 1852-1858. https://doi.org/10.2105/AJPH.2006.090514

60. Shalev AY. 1992. Posttraumatic stress disorder among injured survivors of a terrorist attack: Predictive value of early intrusion and avoidance symptoms. The Journal of Nervous and Mental Disease 180(8):505-509.

61. Shear, M. K. (2015). "Complicated Grief," The New England Journal of Medicine, 372(2), pp. 153-160 (citation from p. 154). DOI:10.1056/NEJMcp1315618

62. Soldatova GV, Chaiguerova LA, Shliapnikov VN. (2008) The psychological consequences of terrorism: the experience of Beslan. Psychol; 30 (6): 1526.

63. Stene, L. E., \& Dyb, G. (2015). Health service utilization after terrorism: a longitudinal study of survivors of the 2011 Utøya attack in Norway. BMC health services research, 15, 158. https://doi.org/10.1186/s12913-015-0811-6

64. Thabet, A. M., Thabet, S. S., \& Vostanis, P. (2016). "The Relationship Between War Trauma, PTSD, Depression, and Anxiety Among Palestinian Children in the Gaza Strip," Health Science Journal, 10(5), p. 1.

65. The National Consortium for the Study of Terrorism and Responses to Terrorism,. (2018, August 27). About START, Retrieved August 17, 2021, from http://www.start.umd.edu/about/about-start

66. Wang, C. W., Chan, C. L., \& Ho, R. T. (2013). Prevalence and trajectory of psychopathology among child and adolescent survivors of disasters: a systematic review of epidemiological studies across 1987-2011. Social psychiatry and psychiatric epidemiology, 48(11), 1697-1720. https://doi.org/10.1007/s00127-013-0731-x

67. Waxman,D. (2011).Livingwithterror,not living in terror: The impact of chronic terrorism on Israeli society. Perspectives onTerrorism, 5, 4-26. 
68. Whalley, M. G., \& Brewin, C. R. (2007). Mental health following terrorist attacks. The British journal of psychiatry : the journal of mental science, 190, 94-96. https://doi.org/10.1192/bjp.bp.106.026427

69. Wu, P., Duarte, C. S., Mandell, D. J., Fan, B., Liu, X., Fuller, C. J., Musa, G., Cohen, M., Cohen, P., \& Hoven, C. W. (2006). Exposure to the World Trade Center attack and the use of cigarettes and alcohol among New York City public high-school students. American journal of public health, 96(5), 804-807. https://doi.org/10.2105/AJPH.2004.058925

70. Yehuda, R., \& Hyman, S. E. (2005). The impact of terrorism on brain, and behavior: what we know and what we need to know. Neuropsychopharmacology : official publication of the American College of Neuropsychopharmacology, 30(10), 1773-1780.

https://doi.org/10.1038/sj.npp.1300817

71. Zinchenko YP, Karabanova OA.(2012) On the road towards a professional community of psychologists: Results of the V Congress of the Russian Psychological Society. J Voprosy Psikhologii; 3: 158161.

72. Zinchenko YP.(2008) Psychology of Safety and Resistance to Terrorism. In: Zinchenko YP, Petrenko VF, editors. Psychology in Russia: State of the Art, 1, Moscow: MSU, p.81 101. DOI: 10.11621/pir.2008.0006. 